\title{
REPRESENTATIONS OF THE FRAGMENTARY IN MODERN ARCHITECTURE
}

\section{A B S T R A C T}

The notion of the fragmentary in philosophical and artistic discourses marks the beginning of modern aesthetics and their detachment from the concept of the whole. This paper illustrates possible resonance fields of the concept of the fragmentary in architecture raising questions such as: Can architecture be a form of expression of the modern condition fragmentaire? Does the notion of fragment develop in architecture in a similar way it did in visual arts, philosophy and literature, or is it being reduced in architecture to a mere form of representation of the fracture? Can the fragmentary be defined as a time based notion and thus emancipate from the usual interpretation of the term as the image of the broken?

\section{Adria Daraban}




\section{FRAGMENTARY ARCHITECTURE}

The notion of the fragmentary occupies a central position in philosophical and contemporary artistic discourses. It marks the beginning of modern aesthetics and their detachment from the concept of the whole. The concept of the fragmentary had already been developed in the early Romanticism as a progressive notion. By the end of the nineteenth century the fragment advanced to a metaphor for a contemporary sense of loss inflicted by the development of new information technologies and their influence on one's perception and a sense of reality. Authors like Georg Simmel, Siegfried Kracauer and Walter Benjamin describe the expression of this modern phenomenon in the field of arts as forms of the ephemeral and the transitory, following Charles Baudelaire's definition of modernity as le transitoire, le fugitif. ${ }^{1}$

This paper illustrates possible resonance fields of the concept of the fragmentary in architecture raising questions such as: Can architecture be a form of expression of the modern condition fragmentaire? Does the notion of fragment develop in architecture in a similar way it did in visual arts, philosophy and literature, or is it reduced to a mere form of representation of the fracture in architecture? Can the fragmentary be defined as a time based notion and thus emancipate from the usual interpretation of the term as the image of the broken?

\section{THE FRAGMENT AS A “MODEL OF WORK" OR AS AN IMAGE OF THE FRACTURE}

The birth of the deconstructivist architecture and one of the most offensive articulations of the fragmentary in the field of architecture took place in 1988. The beginning of the new movement was marked by the exhibition curated by Mark Wigley and Phillip Johnson at MoMa in New York entitled "Deconstructivist Architecture". In March of the same year, the curators proclaim deconstructivist architecture as a turning point and a liberating act from any past architectural form. This paved the way for a new formal language of displacement, distortion, disintegration and rupture, which undermined any notion of the architectural order or the whole. Relating to Jacques Derrida's philosophy of deconstruction, Wigley and Johnson introduced the fragmented forms of deconstructivist architecture as a reflection of a new zeitgeist.

At the same time, the powerful imagery of the fracture, one of the most obvious features behind the deconstructivist form discourse, seemed to provoke some discomfort from the very beginning among its advocates. ${ }^{2}$ Wigley's anxious 
justifications regarding the formal intentions of Decontructivist Architecture are in this regard irritating. Even more discomforting is the curators' insistent claim that the use of distortion and impure forms in architecture were something new. Their description implied that all previous forms of architecture were governed by the classical order and that deconstructive architecture marked a new beginning. It was as if an entire history of architectural forms suddenly disappeared.

Quite a different approach and strategy can be found only a few decades before the birth of deconstructivism in the work of German architect Hans Scharoun (1893-1972). Conceiving space as a form of consciousness (Bewusstseinsform), in the course of his long career Scharoun developed a particular statement in the discourse of the fragmentary in architecture. Also challenging the idea of the universal, he operated with a notion of disparate individual space that is first being constructed through our sequential movement in space and through our perception of space in time. Scharoun's architecture, at first glance composed of disparate elements, fragments and gaps, is a stimulant or an invitation to relate, to put space together through the interpretative act of use.

Unlike the deconstructivist imagery of the fragmentary, Scharoun's concept of the fragment as an operative notion relates to the birth of this notion as a literary "model of work" developed in Jena in the early Romanticism. Phillipe Lacoue-Labarthe and Jean-Luc Nancy noted in their analysis of the German Romantic literary theory The Literary Absolute: The Theory of Literature in German Romanticism published in 1978, that

"Romanticism, then, inaugurates another 'model'of the 'work'. Or rather, to be more precise, it sets the work to work in a different mode (...) This idea orients and informs it first of all by means of the genre in which the Jena Romantics' best-known texts are written, the genre that has become almost inevitably associated with their name: the fragment." ${ }^{3}$

\section{HISTORICAL PRECONDITIONS OF THE FRAGMENTARY: TIME AND THE FRAGMENT OF THE EARLY ROMANTICISM}

In his writings in 1800s Friedrich Schlegel already anticipated the detachment from the aesthetic concept of the whole, which reached its peak in the field of visual arts during the twentieth century. For Schlegel the fragmentary nature was of contemporary importance precisely because it reflected and thereby expressed the sense of incompleteness, openness and potentiality, that has been at the core of the modern achievement and dilemma in the production of art. 
At the same time, he located the notion of the fragmentary as a modern and progressive notion, able to give a new understanding of the production of art and its potentiality linked to the concept of time. In one of the most celebrated and quoted statements defining the modern condition of early modern art and thought, Schlegel wrote in his 24 . Athenaeum Fragment (1798) that, whereas "many works of the ancients have become fragments", and are known only in the form of ruins, "many works of the moderns are fragments at the time of their origin". Schlegel's "fragments from the past" and "the fragments from the future" signalised opposite directions in the timeline, but as German linguist Peter Horst Neumann ${ }^{5}$ underlined, both fragment types share the same aesthetic rank. The two fragment types stand for the concept of the broken and that of the unfinished, traditional expressions of the fragmentary, and become thereby equal.

\section{FRAGMENTS OF MODERNITY:}

\section{THE EPHEMERAL, THE FUGITIVE, THE CONTINGENT}

"There are no wholes in this world; rather, it consists of bits of chance events whose flow substitutes for meaningful continuity."

In his book Fragments of Modernity ${ }^{7}$, British sociologist David Frisby argues, along the writings of Georg Simmel, Siegfried Krakauer and Walter Benjamin, that modernity is an aesthetic concept based on the notion of time and its volatility. In their discourse all three authors relate to political instability, consumerism and new technical developments in the fields of media and transportation with a general sensation of discontinuity, volatility and fragmentation characteristic to the introspective description of the modern age. Central to their discourse is the temporal dimension of the concept of the fragmentary, an argument that follows Baudelaire's phenomenology of modernity. In his essay "The Painter of Modern Life" (1863), Baudelaire gives the concept of modernité a time based definition: "By modernity I mean the ephemeral, the fugitive, the contingent, the half of art whose other half is the eternal and the immutable."

Reflecting Baudelaire, Georg Simmel defines "(the) essence of modernity as such" as

"psychologism, the experiencing (das Erleben) and interpretation of the world in terms of reactions of our inner life and indeed as an inner world, the dissolution of fixed contents in the fluid element of the soul, from which all that is substantive is filtered and whose forms are merely forms of motion." 10 
For both authors modernity is a form of experience, a mixture of fragmentary and contradictory moments, beholden to our inner life. In this context, modern art is defined as a means to capture and articulate this volatility, and for Simmel it is only the sculptor Auguste Rodin (Fig. 1) who is able to embody this concept of fragmentary modernity. Simmel's admiration of Rodin lies in the fact that he had achieved the discovery of "the artistic timelessness of pure movement". "Rodin certainly seeks out the impression but (...) the impression of the supra-momentary, the timeless impression; not that of the particular side or individual moment of objects, but of the object as such (...) Rodin progresses along the path towards a new monumentality - that of becoming, of motion." 11

Simmel's idea of movement as the expression of "the modern soul that is much more unstable, in its attitudes and self-created fates much more changeable"12 than in earlier times certainly anticipated to some extent a new field of interest that had developed by the end of the nineteenth century and beginning of the twentieth century in the visual arts. This involved an increasing awareness of time, space and the human body and led to various experiments, especially among sculptors. This interest had certainly been intensified by the development of photography and cinematography and their impact on the traditional concept of three-dimensionality.

At first, direct means of illustrating the development of movement in space, like the experiments of French physiologist Étienne-Jules Marey (Fig. 2 and 3) served for educational/demonstration purposes. In 1913 the Parisian gallery La Boëtie opened the 1-re Exposition de sculpture futuriste, showing eleven sculptural ensembles of the painter and sculptor Umberto Boccioni. Boccioni,

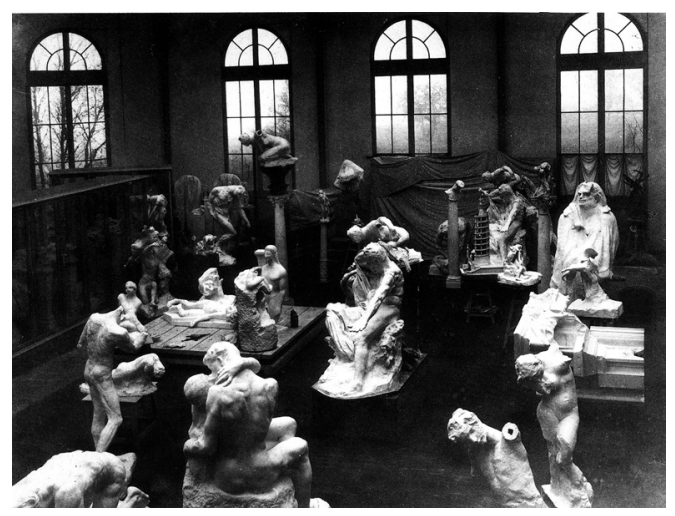

Fig. 1. Atelier of Auguste Rodin, 1904-1905, Photo: Jacques-Ernest Bulloz in Rodin. Eros und Kreativität, Rainer Crone und Siegfried Salzmann (Ed.): München 1991.

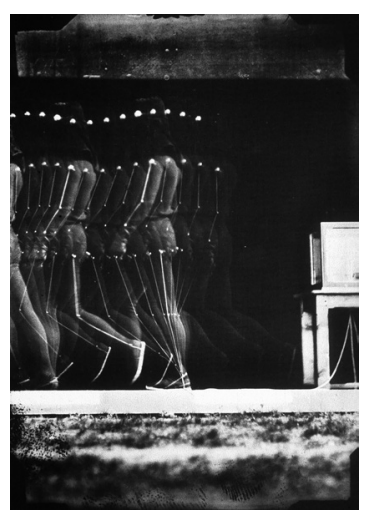

Fig. 2. Étienne-Jules Marey, Chronograph of the human walk, 1884 in Lens-based sculpture : die Veränderung des Skulpturbegriffs durch Photographie ; the transformation of sculpture through photography, Bogomir Ecker and Raimund Kummer Ed.), Köln, 2014 
who was altogether familiar with chronographic imagery, strived to give time a bodily expression by merging different sequences of one movement into a sole figure. A much cited work "Unique Forms of Continuity in Space" (Fig. 4) embodies the idea of a motionless sculpture representing movement in time.

Quite different in the approach, both sculptors struggle to capture the instances of the modern restlessness; while in Rodin's sculptures the totality of time is being fractured and dispersed in tensioned figures, futurist sculpture and cubist painting fracture the figurative representation into multitude of differed time sequences of the same object and overlap these instances on the canvas.

\section{FRAGMENTARY ARCHITECTURE}

The preoccupation with new forms of perception influenced by a multilayered temporality has found different articulations in the artistic avant-garde of the 1920s. Interestingly enough it took architecture quite a long time to relate to these ideas. As British historian Robin Evans points out in his book The Projective Cast: Architecture and its Three Geometries there almost seems to be an antipodal acceptance of the modern avant-garde of 1920s in art on the one hand and in architecture on the other.

"Cubism, especially the painting of Picasso and Braque between 1907 and 1912, was the source of fragmentation in modern art. Modern architecture, on the other hand, is said to be total architecture, monadic to a fault, totalitarian even. Such is the consensus, and yet modern architecture has also been (...) characterised by fragmentation. The intriguing question hereby being: "How could the mainstream of the twentieth architecture be both fractional and total?"13
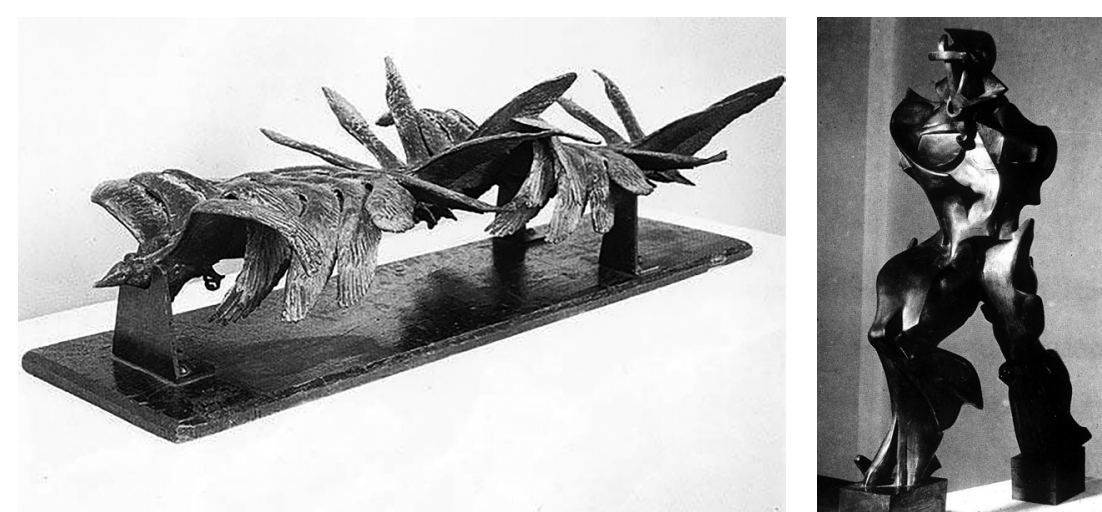

Fig. 3. Étienne-Jules Marey, Analysis of the Flight of a Seagull, 1887 in Lens-based sculpture : die Veränderung des Skulpturbegriffs durch Photographie ; the transformation of sculpture through photography, Bogomir Ecker and Raimund Kummer Ed.), Köln, 2014
Fig. 4. Umberto Boccioni, Unique Forms of Continuity in Space, 19131914, in Lens-based sculpture : die Veränderung des Skulpturbegriffs durch Photographie; the transformation of sculpture through photography, Bogomir Ecker and Raimund Kummer Ed.), 
At this point, the connection between the First World War and the inter-war German avant-garde gives the argument a certain relevancy. "Cultural, art, and political historians see World War I - at once the "seminal catastrophe of the twentieth century" and the "birth of modernity" - as a turning point in the German history, the German cultural production, and the course of avant-garde art and architecture in Germany," 14 as historian Deborah Ascher Barnstone points out in her book The Break with the Past: Avant-Garde Architecture in Germany, 1910-1925. According to Barnstone, the current research on the postwar developments in the creative fields focus almost exclusively on artists and writers, although it was architects such as Walter Gropius, Bruno Taut and Hans Scharoun who led the German avant-garde in the 1920s.

\section{SPACE AND TIME CONCEPTIONS OF THE FRAGMENTARY IN HANS SCHAROUN'S WRITINGS}

"It was - after the First World War - a new departure. The question about the new reality, new form of the collective was posed ... Each of us attempted to convey his worldview." ${ }^{\prime 15}$

Scharoun has spent the war years serving in East Prussia as a military architect. This work and the war experience and the war experience had a major influence on his later work, and historians argue that his post-war distancing from pure Rationalism and Functionalism can be retraced to his experience. ${ }^{16}$ Scharoun's retrospective of the post-war years describes the new spirit that prevailed in the cultural circles in Berlin: it was time for a new beginning, but also the chance to formulate one's worldview through artistic and cultural work. It was a collective impulse which reclaimed new forms of alliances. Under the names Novembergruppe, Glässerne Kette Ring or Arbeitsrat für Kunst different collectives of artists, writers and architects came to life; their declared aim was to unify the arts and make them accessible to every man. Culture was the new religion, the new bond for a new-born society.

Even though he did not immediately return to Berlin, Scharoun engaged in all these groups, becoming one of the major leaders of the avant-garde in Berlin. It was then that Scharoun, inspired by Taut's proclamations on behalf of the Arbeitsrat für Kunst and his books Alpine Architektur and Die Stadtkrone, begins to produce crystalline fantasy drawings. In this period Scharoun also begins his first attempts to articulate his motivation and his theoretical background in the form of manuscripts, essays and lectures. 
On the 3rd of May 1920, the exhibition Ruf zum Bauen - Call to build opened. Adolf Behne writes in the introductory text: "To build means more than just to mason. Building should create the form for our culture." ${ }^{\prime 17}$ Scharoun participated in this exhibition and four of his drawings were published in the catalogue, three of them representing cultural buildings and the fourth a peoples' palace (Volkshaus). Next to one of his drawings we find his text "Gedanken zum Theaterraum"18 (Fig. 5 and 6). The thoughts formulated here marked the beginning of a convolute of writings related to theater in particular and architecture in general, through which Scharoun restlessly tries to formulate his own Künstlertheorie over the years. His argument begins with the description of what he calls the conventional theatre, its constricting and estranging space as an antipode of the new theater, later being less a form of space but more of a composition of sensations, visual, audial and spatial. Here form becomes "collective consciousness" and "collective experience". "House, object, human - unitary reflection of time seeing: one art, one life."19

One year later, in his talk "Thoughts about the Modern Scenery" (Gedanken über das moderne Bühnenbild) in Königsberg, Scharoun again theorises the idea of the scenic concept as an allegory for architecture. For the first time, he formulates his interest in "the fourth dimension" of space, the temporal dimension, by pointing to cinematography as the first medium to be able to capture the symbiosis between space and time, characteristic for the modern society and modern thought. Modern theatre, and beyond that modern space, should follow this impulse because

"it is the bond between space and time realised in film, that represents the Dynamic, the element that gives a soul to our technic oriented society and exercises an unknowingly attraction on the viewer." ${ }^{20}$

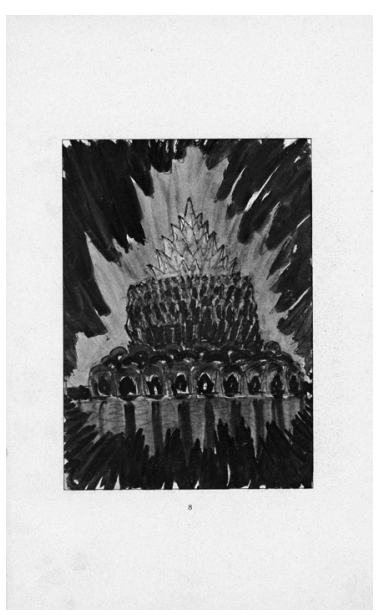

Fig. 5. Hans Scharoun, Kultbau in Ruf zum Bauen, AfK, Berlin, 1920, Archiv der Akademie der Künste Berlin, Abteilung Baukunst.

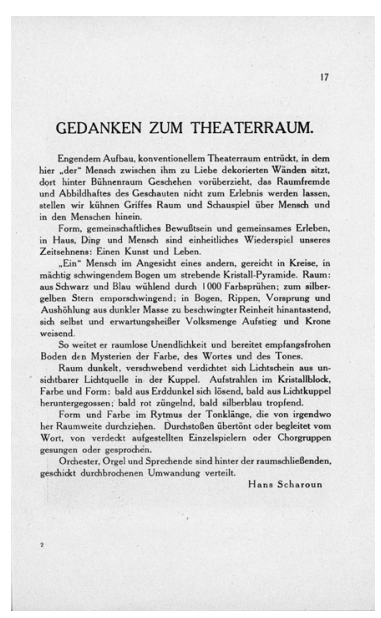

Fig. 6. Hans Scharoun, Gedanken zum Theaterraum in Ruf zum Bauen, AfK, Berlin, 1920, Archiv der Akademie der Künste Berlin, Abteilung Baukunst. 
From now on, the interest in the effect of the temporal dimension in the formation and perception of space will remain a constant in Scharoun's writings. His inaugural lecture in 1925 in Breslau was the earliest and most thorough and decisive articulation of his theory of space. By pointing to the volatility of modern perception to its shattering into a multitude of fragmentary impressions, Scharoun again insists on the role of the concept of time in the perception of space, pointing to the dissolution of this relationship in modern space concepts. ${ }^{21}$ Of course Scharoun's arguments on the multi-temporal nature of space are deeply anchored in the cultural discourse of his time. The architect himself mentioned the fortuitous and early discovery of the futurist exhibition Der Sturm at Herwath Walden's gallery. ${ }^{22}$ Many authors have also pointed to Scharoun's friendship with the artist Kurt Schwitters and speculated on the influence of his work upon the architect's space conception. Scharoun describes on several occasions the synergetic spirit that he came across in his first years in Berlin. Encounters between architecture, visual arts, literature and music, all under the flag of the new beginning: "(s)pontaneity is the mark of this time, improvisation - its essence - improvisation supports the freedom of choice in its nativeness." ${ }^{23}$

All of Scharoun's thoughts on theatre designs remained a theory until 1949. He had already designed two theatres - for the cities of Gelsenkirchen and Bremerhaven - in the early '20s but his experiments with the scenic design actually begin 1949 with the competition for the Leipzig opera house and with the design for a concert hall, the Liederhalle, in Stuttgart. In 1952, Scharoun won the competition for the Theatre in Kassel, together with the landscape

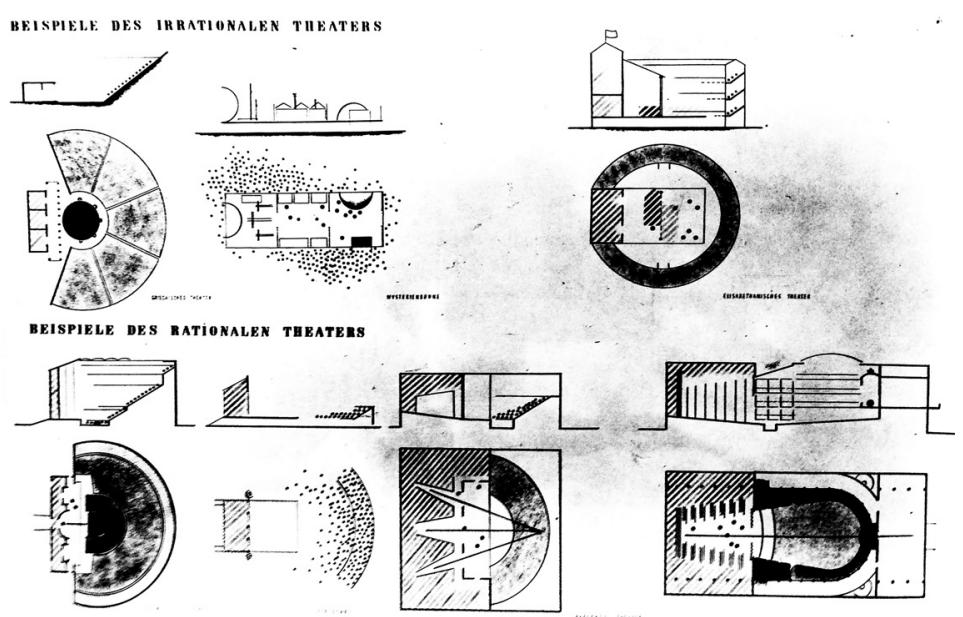


architect Hermann Mattern and the theatrical consultant Wilhelm Huller. He entered the competition for the Mannheim National Theatre in 1954, and then submitted a design for the Gelsenkirchen theatre, competed for the Zürich city theatre in the mid-' 60 s, and finally the Wolfsburg Theatre, the only theater he was able to build.

One of Scharoun's most daring theatre concepts, the design for the Mannheim National Theatre, was also the occasion to deepen his studies in history and theory of theatre. For this competition, Margot Aschenbrenner, Hugo Häring's assistant, wrote for the essay "Über die Baustruktur des Theaters". Following her differentiation between the "rational" and the "irrational" theatre, Scharoun works most intensively on the possibilities of a new relation between play and audience, as implied by the irrational Shakespearean theatre. Commenting on the project, Scharoun superimposes on the notions of the rational and irrational theatre (Fig. 7), the ones of the perspectival or a-perspectival space, a terminology that he had often made use of. In post-war Germany, Swiss philosopher Jean Gebser and his notion of a-perspectival consciousness had some influence and was also been adopted by Scharoun, who had met Gebser personally. Gebser's book Ursprung und Gegenwart, which was published in 1949, was often read in the German intellectual circles. The book evolves around the theory of the a-perspectivical consciousness, a form of integral consciousness, a stage of consciousness first reached in the new age that combines the rationalism of the Enlightenment and the mythical, magical thinking of the Earlier Ages. Gebser argues, that this state of integral consciousness manifests itself not only in natural sciences, especially in the domain of physics, but also in painting, architecture and music, the feature common to all these fields being the integration of a fourth dimension of perception, the dimension of time.

In his explanatory text for the National Theatre in Mannheim (Fig. 8, Modell) in 1953, Scharoun sketches the difference between what he calls the perspectivical and the a-perspectivical theatre. For his argument he differentiates between the linear and the juxtaposed nature of time in the two types of theatre. "Whilst the perspectivist theatre contents the succession - 'physical chain reaction' and perspectivity correlate - whilst it expresses a time concretion to which space subordinates, the a-perspectival theatre contains the 'side by side' and the 'on top of each other' - in the wholeness of time - due to the new time concretion, expressed through the sequences of movement and through the polar reference to 'places'. The wholeness of time materializes through space." Quoting Heidegger's speech in Darmstadt, "Bauen Wohnen Denken", Scharoun states: "Der Raum wird durch Orte eingeräumt."24 


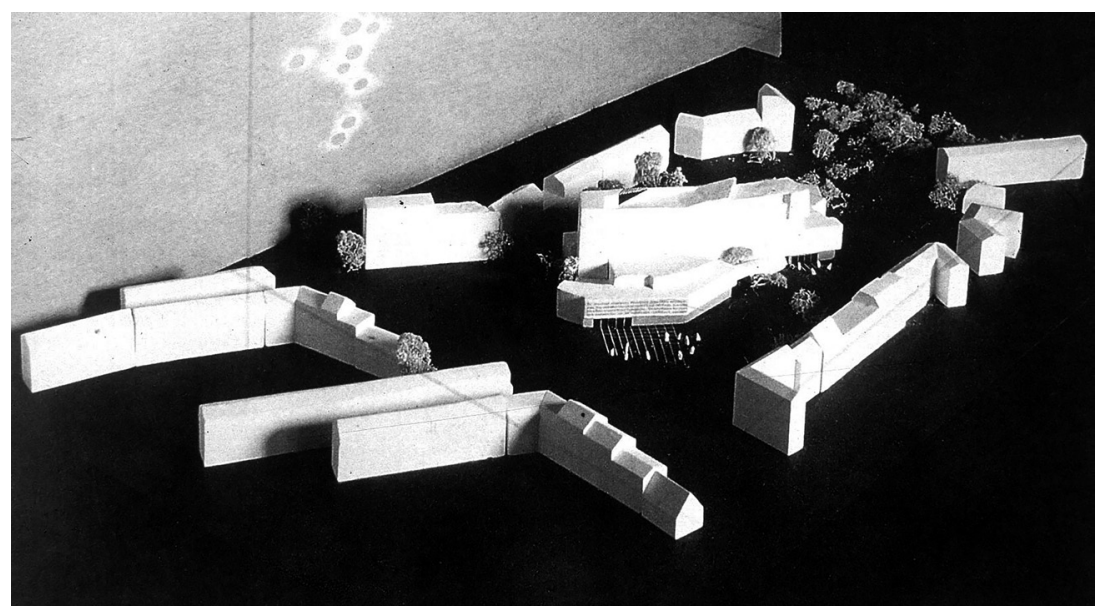

Fig. 8. Hans Scharoun, National Theatre Mannheim, Model, 1953, in Hans Scharoun. Bauten, Entwürfe, Texte, Schriftreihe der Akademie der Künste, Pfankuch, Peter (Ed.): Bd. 10, Berlin 1993.
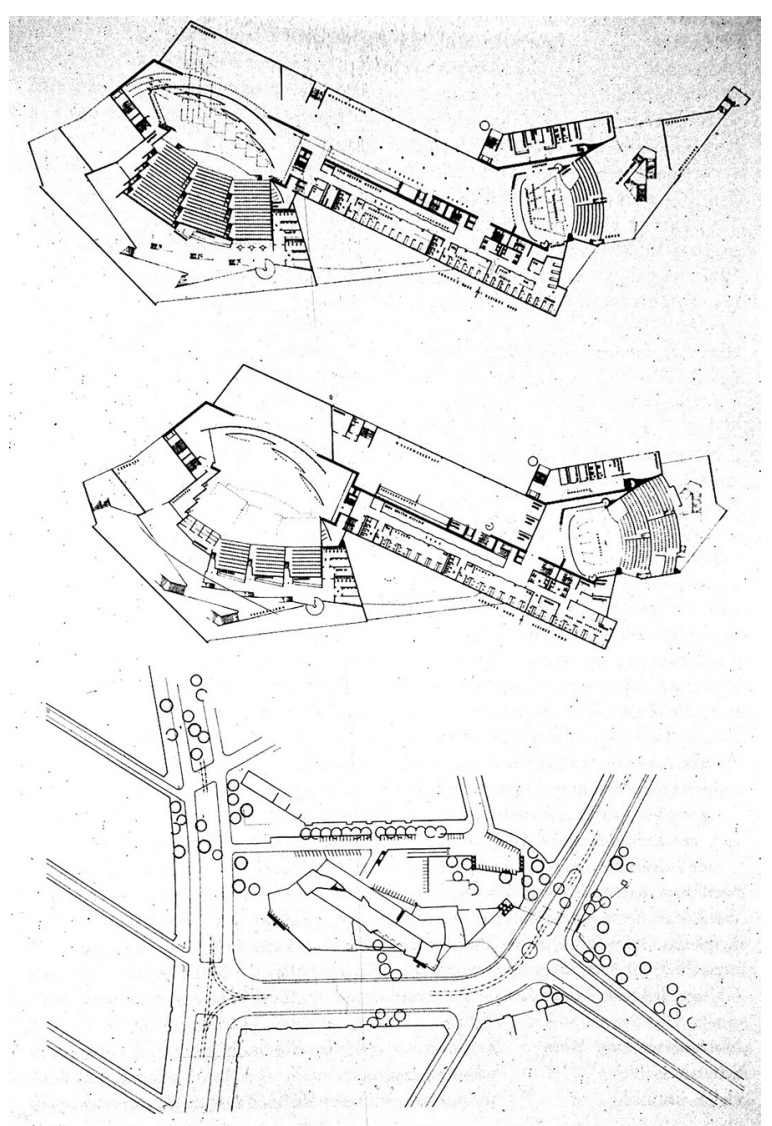

Fig. 9. Hans Scharoun, National Theatre Mannheim, Model, Floor plans, 1953, in Hans Scharoun. Bauten, Entwürfe, Texte, Schriftreihe der Akademie der Künste, Pfankuch, Peter (Ed.): Bd. 10, 
The layout and the complex disposition of the theatre design for Mannheim (Fig. 9) is characterised by the abandonment of symmetry for the auditorium. The space is whether centralised, nor divided into halves. The audience seating is divided into groups with separate entrances from the foyer. The orientation is given through different angles, which refuse the single focus. The stage can be used in different parts and at different heights or it can be used sequentially. Peter Blundell Jones points out in his monograph on Scharoun to the time specific space concept in Scharoun's Mannheim auditorium by stating that: "(T)he changing locations in time introduce the fourth dimension as opposed to the static three-dimensionality of the perspective theatre." ${ }^{25}$

Scharouns uses many distractions in order to guide and, at the same time, disrupt the way people move through its foyer. Scharoun does not only compose a whole scenography of movement in theatre design, his school designs ${ }^{26}$ operate similarly. He displaces elements, changes levels, stages views on the city, forces the visitors to turn in order to reach the staircases or the entrances. It is a strategy that will be perfected in the design of the Berlin Philharmonic.

Scharoun's space concept proves modern in two respects. On the one hand, it seems to favour the particular to the universal; the multidimensional to the linear, the disparate to the whole, but more relevant is his recurrent attempt to define space as a form of consciousness. In his speech on the Darmstädter Gespräch from1951 entitled Mensch und Raum, Scharoun speaks, relating to Kant, about space as a form of consciousness and time as a form of gaze - "Raum als Bewußtseinsform" and "Zeit als Anschauungsform". ${ }^{27}$ In his argument he alludes to modern music and cubist painting:

"The ones who dealt with new music or with the painting of Braque and Picasso etc. can see that also there different states of time have been balanced to a new time concretion - so that different levels of consciousness are to some extent simultaneously operating and taking effect or they are bringing different facts together into one Reality." 28

Scharoun's argument here cumulates in the assumption that all form of consciousness is based on a multi-temporal construction, and consequentially that space cannot anymore be perceived in this wholeness, but only on the basis of disparate but coordinated "states of time".

Looking back at Wigley's attempt to discern between formal and non-formal manifestations of the fragmentary in architecture, Scharoun seems to have found a much more subtle way to approach the notion of the fragmentary as 
a time based notion decades before the opening of the 1988 deconstuctivist exhibition in MoMa. His argument was not a formal one. He was far too interested in space, context and use; his intention was to involve the viewer in the development of the space around, and his interests lied in the relationships, polarities, adjacencies, connections, rather than in the manipulation of the image.

At this point one could even go as far as to draw a parallel with Rodin's idea of the sculptural body as a "progressive unfolding", a fragmented figure of movement in which "the sculptor represents the transition from one pose to another" and "thus compel the viewer, so to speak, to follow the development of an act through one figure." Following this thought, the architectural body could also be seen as the embodiment of sequential movement, progressively unfolding through the perceptive act of its user. Other Essays, translated and edited by J. Mayne (London: 1955), 1-40.

This became obvious in Mark Wigleys introductory contribution for the exhibition catalogue, where he tried to point out the difference between projects physically deconstructed or destroyed and the projects exhibited, where the deconstruction takes place on a meta-level through questioning the constitution of architecture as a discipline and not it's physical materialization. See in Philip Johnson and Mark Wigley, Deconstructivist Architecture (New York, 1988), 11. German Romanticism, trans. Phillip Barnard and Cheryl Lester(Albany: State University Press of New York, 1988), 59. Huyssen (Stuttgart: 2010), 99. 
Sigfried Krakauer, Theory of Film. The redemtion of physical reality (Princeton: 1997), 297.

David Frisby, Fragments of Modernity. Theories of Modernity in the Work of Simmel, Krakauer and Benjamin (Cambridge: 1985), 271.

C. Baudelaire, "The Painter of Modern Life," in C. Baudelaire, The Painter of Modern Life and Other Essays, translated and edited by J. Mayne (London: 1955),1-40.

Ibid., 3 .

Georg Simmel, "Die Kunst Rodins und das Bewegungsmotiv in der Plastik," Nord und Süd. Eine deutsche Monatsschrift, 129. Band, 33. (Mai 1909): 189-196.

Ibid.

Ibid.

Robin Evans, The Projective Cast. Architecture and its Three Dimensions (Cambridge, London: 1995), 57.

Deborah Ascher Barnstone, The Break with the Past: Avant-Garde Architecture in Germany, 19101925 (London and New York: Routledge Research in Architecture, 2017), 18. Referring to: Modris Eksteins, Rites of Spring: The Great War and the Birth of the Modern Age (New York: Mariner, 1989); Kenneth E. Silver, Esprit de Corps: The Art of the Parisian Avant-Garde and the First World War (Princeton, 1992).

Hans Scharoun: "Die gläserne Kette,” Lecture at the radiostation Freies, Berlin, March 14, 1964, Scharoun Archive, AdK.

See also Barnstone, p.161.

Adolf Behne, "Bauen ist etwas mehr als Mauern. Das Bauen soll die Form schaffen für unsere Kultur," in Ruf zum Bauen, $2^{\text {nd }}$ publication of the Arbeitsrat für Kunst (Berlin: Adk, Baukunstarchiv, 1920), 2. Ibid., 8 .

Ibid. "Haus, Ding und Mensch sind einheitliches Wiederspiel unseres Zeitsehens: Eine Kunst und ein Leben", 8.

"Und weiter ist es die im Film erreichbare Verbindung von Raum und Zeit, die das Dynamische, das der Kultur unserer Technik orientierten Zeit Seele gibt und das unbewußten Reiz auf den Zuschauer ausübt.” in Hans Scharoun, "Gedanken zum Theaterbau”, lecture held in Königsberg, 1921, Manuscript published in the Schrifterreihe der AdK, Berlin, 1993, Vol. 22, p. 28.

Hans Scharoun, "Inaugural lecture at the Art Academy in Breslau 1925," in Hans Scharoun. Bauten, Entwürfe, Texte, ed. : Peter Pfankuch (Berlin: 1993), 48-54.

Hans Scharoun, "Introduction for the opening of the Expressionist Exhibition at the AdK 1961," Schrifterreihe der AdK, Vol. 22 (1993): 41.

Ibid.

Hans Scharoun, "Explanatory text to the National Theatre in Mannheim,1953," in Hans Scharoun. Bauten, Entwürfe, Texte, ed. Peter Pfankuch (Berlin: Schriftreihe der Akademie der Künste, Bd. 10, 1993), 223.

Peter Blundell Jones, Hans Scharoun (London. 1995), 161.

See also Adria Daraban, "Konstellationen des Denkens. Hans Scharouns Geschwister-SchollSchule in Lünen - eine frühe Alternative zur Moderne," archithese 3 (2016): 78-84.

"Kant hat den Raum, der keine außer uns und unabhängig von uns bestehende Dinglichkeit sei, als Bewußtseinsform determiniert. Form des Bewußtseins setzt das Besondere, Unterscheidbare, Vergleichbare voraus oder, anders ausgedrückt, [es] wandelt sich der Subjekt-Objekt Bezug, wie Ich und Inhalt sich wandeln oder untereinander verschieden sind. Wissen wir um diese und um deren wirksame Bezüge, so können wir uns das Wesenstümliche anschaulich vorstellen und Tendenzen wirksam werden lassen," Hans Scharoun, "Mensch und Raum," in Mensch und Raum, 
ed. Ulrich Conrads / Neitzke, Peter. Das Darmstädter Gespräch 1951 mit wegweisenden Vorträgen von Schwarz, Schweizer, Heiddeger, Ortega y Gasset, Bauwelt Fundamente, Bd. 94, Braunschweig

"Wer sich mal mit der neuen Musik oder auch mit der Malerei eines Picasso, eines Braque usw. auseinandergesetzt hat, sieht auch hier, daß verschiedene Zeit-Zustände in einer neuen Zeitkonkretisierung aufeinander abgestimmt sind - so, daß verschiedene Bewußtseinsebenen gewissermaßen gleichzeitig tätig und wirksam sind oder verschiedene Tatsachen zu ,einer Wirklichkeit bringen.” Ibid. p. 114-115.1991, p. 113. 
Ascher Barnstone, Deborah. The Break with the Past: Avant-Garde Architecture in Germany, 19101925. London and New York: Routledge Research in Architecture, 2017.

Baudelaire, Charles. "The Painter of Modern Life." In Baudelaire, Charles: The Painter of Modern Life and Other Essays, translated and edited by J. Mayne, 1-40. London: 1955.

Blundell Jones, Peter. Hans Scharoun. London: 1995.

Conrads, Ulrich and Peter Neitzke, Ed. Mensch und Raum. Das Darmstädter Gespräch 1951 mit wegweisenden Vorträgen von Schwarz, Schweizer, Heiddeger, Ortega y Gasset, Bauwelt Fundamente, Bd. 94, Braunschweig, 1991.

Evans, Robin. The Projective Cast. Architecture and its Three Dimensions. Cambridge, London: 1995.

Frisby, David. Fragments of Modernity.Theories of Modernity in the Work of Simmel, Krakauer and Benjamin. Cambridge: 1985.

Johnson, Philip and Wigley, Mark (Ed.). Deconstructivist Architecture. New York: 1988.

Lacoue-Labarthe, Phillipe and Nancy, Jean-Luc. The Literary Absolute: The Theory of Literature in German Romanticism, Translated by Phillip Barnard and Cheryl Lester. Albany: State University Press of New York, 1988.

Neumann, Peter Horst. "Rilkes archaischer Torso Appolos in der Geschichte des modernen Fragmentarismus." In Fragment und Totalität, edited by Dällenbach, Lucien und Hart Nibribrig, Christiaan. Frankfurt a.M.: 1984.

Pfankuch, Peter (Ed.). Hans Scharoun. Bauten, Entwürfe, Texte, Schriftreihe der Akademie der Künste, Bd. 10, Berlin 1993.

Rodin, Auguste. Die Kunst. Gespräche des Meisters gesammelt von Paul Gsell. Zürich: 1979.

Schlegel, Friedrich. Athenäums-Fragmente und andere Schriften, Selection and postface by Andreas Huyssen. Stuttgart: 2010.

Simmel, Georg. "Die Kunst Rodins und das Bewegungsmotiv in der Plastik in Nord und Süd.” Eine deutsche Monatsschrift, 129. Band, 33. (Mai, 1909): 189-196. 
utkane u asocijativni, oscilirajući tok misli, često komentarušući urbanog šetača kao glumca u kapitalističkom društvu. Za razliku od toga, Niče smatra da doživljaj arhitektonskog prostora može biti sagledan kao sveobuhvatna sinteza unutrašnjeg života i spoljašnjeg iskustva, tj. preplitanje misli i pokreta, udomljujući (pomirujući) novu kreativnu dispoziciju sa stanjem svesti.

KLJUČNE REČI: FRIDRIH NIČE, VALTER BENJAMIN, FLANEUR, ATMOSFERA, URBANI PEJZAŽ, METROPOLA

\section{EPISTEMOLOŠKE IMPLIKACIJE NEUROARHITEKTURE}

\section{Hana Samaržija}

Ovaj rad će pokušati da objasni kako prostorne karakteristike izgrađenih okruženja utiču i na kognitivne procese proizvodnje znanja i epistemički kvalitet drugih logika ubeđenja. Skorije diskusije u filozofiji i društvenim naukama eksplicitno govore o promenjivoj dinamici savremenog života. Kako zamagljene granice između rada i slobodnog vremena primoravaju pojedince da utroše najveći deo svog vremena u izgrađenim okruženjima, lična iskustva prostora, objekata i enterijera postaju odlučujući faktor u samo-percepciji i spoznaji. Ove okolnosti su ohrabrile dolazak nove naučne oblasti: neuroarhitekture, ogranka funkcionalnog dizajna podržanog tehnologijom neurološkog skeniranja mozga i konceptom neuroplastičnosti, odnosno kapaciteta mozga da promeni svoju strukturu paralelno sa našim ponašanjem i okolinom. Ovaj rad nakon razmatranja ambicija neuroarhitekture da definiše najpoželjnije prostore po kriterijumu pozitivnih emocija, dobrog zdravlja, i intelektualne krepkosti, kritički će proceniti svoje epistemološke implikacije i njen potencijalno nepovoljan uticaj na arhitektonsku estetsku autonomiju. Ovaj upliv prirodnih nauka u prividno artistički domen arhitekture podseća nas na razlike između tradicionalnih analitičkih filozofija - koje su se bavile idealizovanim modelima intelektualnih i mentalnih procesa - i uvidom nauke u ljudske spoznaje, možda najbolje ilustrovana teorijom identiteta uma-mozga.

KLJUČNE REČI: NEUROARHITEKTURA, EPISTEMOLOGIJA, SPOZNAJA, UM-MOZAK IDENTITET, FILOZOFIJA UMA

\section{PREDSTAVLJANJE FRAGMENTARNOG U MODERNOJ ARHITEKTURI}

\section{Adria Daraban}

Pojam fragmentarnog u filozofskim i umetničkim diskursima obeležava početak moderne estetike i njihovo odvajanje od koncepta celine. Ovaj rad ilustruje moguća rezonantna polja oko pojma fragmentarnog u arhitekturi koji postavlja pitanja: Može li arhitektura biti oblik izražavanja savremenog stanja fragmentarnog? Da li se pojam fragmenta razvija u arhitekturi na sličan način kao i u oblastima vizuelne umetnosti, filozofije i književnosti, ili je fragment u arhitekturi sveden isključivo na oblik prezentovanja preseka? Može li se fragmentarno definisati kao pojam uslovljen vremenom i tako osloboditi od uobičajenog tumačenja pojma kao slike o isečku?

KLJUČNE REČI: FRAGMENT, HANS ŠARUN, AVANGARDNA ARHITEKTURA U NEMAČKOJ, NEMAČKI ROMANTIZAM, OGIST RODEN, FUTURIZAM

\section{KOLATERALNA LEPOTA: NICEOVA RAZMIŠLJANJA 0 ARHITEKTURI}

\section{Mirza Vranjaković}

Sa svojim tumačenjem apolonijskog i dionizijskog stanja u psihologiji, Niče (Nietzsche) je pokušavao da poveže eminentne dihotomije svoje ere - razum i instinkt, nauku i metafiziku, iskustvo i promišljanje, znanje i inspiraciju, pojavnost i celinu, red i haos. Kroz ovaj dualizam, on se kritički osvrće na celokupno nasledje zapadnjačke kulture. Predmetni rad analizira nekolicinu Ničeovih aforizama koji su direktno ili indirektno odnose na "umetnost izgradnje". Kroz aforizme, Niče je prizivao ideju nove arhitekture koja će se usprostaviti idealu zgrade devetnajstog veka: arhitektura ne idealizuje, ona nije samo pojava, već je izgrađena u duhu svog vremena, i navodi da se u nju uselimo, i na kraju, u arhitekturi lepota nije kraj već sredstvo za postizanje cilja. 